\title{
The Inner Horde in the light of Comparison of Empire Management Practices
}

\author{
DOI: $10.31551 / 2410-2725-2019-5-3-419-430$
}

\section{Galiev Anuar Abitaevich}

Doctor of Historical Sciences, Professor at the Ch.Valikhanov Institute of History and Ethnology, of Kazakhstan, Almaty. E-mail: galiev_anuar@mail.ru

\begin{abstract}
The paper discusses the management system that existed in the Bukeyevsky Khanate, which was formed in the early XIX century between the Volga and the Urals. The initiative to create it came from the Royal officials. There, some forms of government were introduced that were previously applied in other ethno-political formations that existed previously on the territory of the Russian Empire, and a new form of relationship was built between the ruling elite of the Kazakhs of this Khanate and the Royal authorities. All these forms and methods of management differed from traditional ones, therefore they can be understood as "invented traditions".

The Bukeyev Horde, de facto, was located in the European part of the Empire, that is, in the immediate vicinity of the most economically and culturally developed areas of the country, and its Khans, also had begun to introduce various elements in management that were not previously known.

The creation of such political entities was known in the practice of governing various Empires, including those created by Madrid in the Americas. As Benedict Anderson showed, this practice led to the emergence of new states independent of Spain. In the case of the Bukeyev horde, this did not happen for various reasons of a geographical, social and economic nature. The Horde that had existed for about half a century as a testing ground for working out the forms of relations between Russia and its new subjects, was eliminated since Russia strengthened its position in this region, and abolished Khan's power, relying on Chingisism, and approved its new institutions there.
\end{abstract}

Key words: Bukeyev Horde; Russian Empire; invented traditions; imaginary community.

\section{Империяның басқару тәжірибесін салыстырудағы Алтын Орда}

\section{Галиев Ануар Абитаевич}

тарих ғылымдарының докторы, Ш.Ш. Уәлиханов атындағы Тарих және этнология институтының профрессоры, Қазақстан, Алматы қ., E-mail: galiev_anuar@mail.ru

\begin{abstract}
Андатпа. Осы аталмыш ғылыми мақалада XIX ғасырдың басында Еділ мен Жайық өзендерінің арасында қалыптасқан Бөкей Ордасындағы басқару жүйесі жан жақты ғылыми әрі жүйелі түрде нақты қарастырылған. Бөкей Ордасын қалыптастыру туралы бастама патша үкіметінің шенеуніктері тарапынан көтерілгені белгілі. Осы бастама негізінде бұрында Ресей империясы құрамында болған өзгеде этносаяси бірлестіктерде болған және қолданылған тәжірибе негізінде жаңа қалыптасқан саяси Ішкі Орда бірлігінде қазақ ақ сүйектері мен патша билігі арасында жаңадан өзара қарым-қатынас орнату мәселесінде аталмыш тәжірибені енгізу мәселесі жан жақты баяндалған. Патша билігінің осы басқару жүйесін салыстырмалы түрде алып қарайтын болсақ, осыған дейінгі болған дәстүрлі жүйеден ерекше болғандықтан, аталмыш жүйені біз «жасанды дәстүр» деп толық негізде айта аламыз. Бөкей Ордасы іс жүзінде Ресей империясының еуропалық бөлігінде орналасуы және империяның неғұрлым экономикалықмәдени тұрғыдан дамыған аудандарына жақын орналасуы фракторлары Ішкі Орда билеушілерін басқарудын әлі белгісіз жаңа түрлерін енгізуге итермелейді. Әлемдік империялар тарихын алып қарайтын болсақ, империялық басқарудың осындай тәсілдері Испан империясының Америка құрлығында қолданғаны бізге белгілі. Зерттеуші Бенедикт Андерсон атап көрсеткендей дәл осындай саяси басқару жүйелері кейін испан империясынан тәуелсіз жаңа мемлекеттерді дүниеге әкелді. Ал осындай жағдай әртүрлі географиялық, әлеуметтік және экономикалық сипаттағы себептерге байланысты Бөкей Ордасында іске асырыла алмады. Бөкей Ордасы жарты ғасырдай уақыт өмір сүрді. Ол патша билігінің отарды жаңаша басқару саясатының сыналған аймағы ретінде тарих қойнауында қала берді. Ал патшалық Ресей аталмыш аймақта өзінің отаршылдық басқару позициясын күшейтіп алғаннан кейінгі тарихи кезеңде шыңғыстық хандық басқару жүйесіне негізделген Бөкей Ордасы жойылып, бұл аймақта басқарудың жаңа тетіктері мен институттары енгізілгені мәлім.
\end{abstract}

Түйін сөздер; Бөкей Ордасы; Ресей империясы; жасап шығарған дәстүрлер; қиялдағы қауымдастық. 


\title{
Внутренняя Орда в свете сравнения практик управления империй
}

\section{Галиев Ануар Абитаевич}

доктор исторических наук, профессор Института истории и этнологии им. Ч. Валиханова, Казахстан, Алматы. E-mail:galiev_anuar@mail.ru

\begin{abstract}
Аннотация. В статье рассматривается система управления, существовавшая в Букеевском ханстве, образованном в начале XIX в. в междуречье Волги и Урала. Инициатива его создания исходила от царских чиновников. Здесь внедрялись некоторые формы управления, ранее применяемых в других этнополитических образованиях существовавших ранее на территории Российской империи, выстраивалась новая фоорма взаимоотношений между правящей элитой казахов этого ханства и царскими властями. Все эти формы и методы управления отличались от традиционных, поэтому они могут быть поняты как «изобретенные традиции».

Букеевская Орда, де фракто, располагалась в европейской части империи, то есть в непосредственной близости от наиболее развитых в экономическом и культурном отношениях районов страны, и ее ханы, также начинают внедрять различные элементы в управлении, которые ранее не были известны.

Создание подобных политических образований было известно в практике управления различных империй, в том числе и тех, которые были созданы Мадридом на американском континенте. Как показал Бенедикт Андерсон, подобная практика привела к появлению новых независимых от Испании государств. В случае с Букеевской Ордой это не произошло по различным причинам географического, социального и экономического характера. Просуществовавшая около полувека в качестве полигона, где отрабатывались формы взаимоотношений России со своими новыми подданными, Орда была ликвидирована, потому, что Россия укрепила свои позиции в этом регионе, упразднила ханскую власть, опиравшуюся на чингисизм и утвердила здесь новые институты.

Ключевые слова: Букеевская Орда; Российская империя; изобретенные традиции; воображаемое сообщество.
\end{abstract}

\section{УДК/UDC 94 (574)}

\section{Внутренняя Орда в свете сравнения практик управления империй}

\section{А.А. Галиев}

Введение. В современной казахстанской историографии существует немало нерешенных и малоисследованных проблем. Причиной этого является не только недостаток источников, но и узость теоретико-методологической базы. Сказанное относится и к периоду вхождения Казахстана в состав Российской империи.

Так, прежняя казахстанская историография основывалась на марксистсколенинской теории классовой борьбы и все явления и процессы, происходившие на территории нашей страны, подгонялись под эту теорию, что не позволяло адекватно оценивать реальную картину. Так, социально-экономические отношения в казахском кочевом обществе определялись как фреодально-патриархальные. Сам Казахстан однозначно признавался колонией. С распадом СССР и соответственно крушением марксистско-ленинской теории, стало очевидным, что существующие объяснения не всегда удовлетворительны. В частности, были высказаны сомнения в том, являлся ли Казахстан колонией (Трепавлов,2001).

Для ответа на этот и другие вопросы необходимо не только изучение взаимоотношений между царским правительством и управляемым им казахским народом, но и рассмотреть формы и методы этого управления. Кроме того, необходим и сравнительно-исторический анализ систем управления существовавших в Российской и других империях. Подобная работа, проводимая японскими коллегами, показывает перспективность разработок в этом направлении (Uyama, 2012; Comparing, 2018) 
Естественно, что полное понимание взаимоотношений между СанктПетербургом и Казахстаном, фрорм и методов управления не может быть достигнуто в одной статье, поэтому наша задача будет намного скромнее: она заключается в рассмотрении вопросов, связанных с системой управления, существовавшей в самой западной части Казахстана - Букеевском ханстве.

Методология. В работах, прежде всего, западных ученых исследующих проблемы возникновения государств и наций в новое и новейшее время, успешно применяется теория конструктивизма. Так, Бенедикт Андерсон, в монографрии «lmaginedcommunity» продемонстрировал процесс создания наций в Латинской Америке и Юго-Восточной Азии. Он прекрасно показал, что появлению государств Латинской Америки предшествовало создание Мадридом административных единиц, что было обусловлено и природно-климатическими условиями и обширностью империи (Андерсон, 2001).

Между тем, подобная практика осуществлялась не только такими державами как Испания, Франция, Великобритания, но и Российской империей.

Повсеместно, при управлении колонизуемыми территориями, империи прибегали либо к прямому, либо непрямому (косвенному) управлению, либо к комбинации элементов обоих типов управления (Томсинов, 1981; Крупенкин, 2018). Зачастую при этом использовались либо традиционные институты, либо их модернизированные варианты, либо полностью изобретенные традиции. Изучению последних, в контексте национального и государственного строительства, были посвящены исследования Эрика Хобсбаума (Хобсбаум, 1983). При написании данной статьи автор опирался на основные положения, разработанные Б.Андерсоном и Э.Хобсбаумом.

Выше было упомянуто, что практика создания политических образований существовала и в Российской империи. Одним из примеров подобного рода является создание Букеевской Орды (ханства) в Волго-Уральском междуречье.

Термин «изобретенная традиция» Э.Хобсбаум использует здесь в широком, но достаточно точном смысле. Им охватываются как «традиции» действительно изобретенные, сконструированные и формально институционализированные, так и те, появление которых проследить труднее, но которые, тем не менее, быстро утверждались в течение короткого, поддающегося датировке периода времени, исчисляемого, пожалуй, всего несколькими годами.

«Изобретенная традиция» - это совокупность общественных практик ритуального или символического характера, обычно регулируемых с помощью явно или неявно признаваемых правил; целью ее является внедрение определенных ценностей и норм поведения, а средством достижения цели повторение. Последнее автоматически предполагает преемственность во времени.

Второе, менее важное, различие, которое необходимо провести, - это различие между «традицией» в нашем ее понимании и заведенным порядком или правилом. По своей сути порядок и правило не обладают скольконибудь значительной ритуальной или символической функцией, хотя и могут ее обрести случайным образом (Хобсбаум, 1983: 1-14).

В целях управления созданным в начале XIX в. новым этнополитическим образованием, царское правительство применяло нетрадиционные фрормы управления, которые могут рассматриваться как изобретенные традиции.

Дискуссии. Попытка рассмотреть процесс приобщения населения Северного Прикаспия к имперскому пространству путем трансформации некоторых традиционных ритуалов (т.е. изобретения традиции), в том числе обряда избрания хана, была предпринята Ж.Кундакбаевой (Кундакбаева, 
2014). Для понимания тех изменений, которые произошли в традиционной казахской системе управления, необходимо понять, что такое казахская государственность в условиях кочевого скотоводства, при этом следует учитывать не только те работы, которые были созданы в советское время под влиянием марксистско-ленинской теории общественного развития, опирающейся на концепцию эволюционизма, но и на работы, созданные на иной теоретической базе. К их числу можно отнести монографию американского ученого Д.Сниза. Он изучил многие кочевые общества, в том числе казахское, традиционно рассматриваемые как безгосударственные, родовые и сформулировал теорию о «государстве без главы», конфигурации государствоподобной власти, сформированной горизонтальными связями между власть предержащими, а не в результате взаимного подчинения политическому центру (Sneath, 2007:1).

Д.Сниз назвал «государством без главы» политическую среду, в которой почти все действия государственной власти существуют на локальном уровне фактической независимости от центральных бюрократических властей (Sneath, 2007:5).

Важно также иметь в виду, что система управления, применяемая кочевниками в оседло-земледельческой среде, отличалась от той, которая существовала собственно в степи. Автор данной статьи попытался показать это на примере Казахского ханства (Sneath, 2007:27).

Оспаривая мнение об анархии, безгосударственности казахов, Д.Сниз на основе анализа различного материала и особенно критического переосмысления труда А.Левшина, приходит к выводу, что «нестабильность казахского общества в левшинское время была результатом подрыва ранней более централизованной системы ханства. Согласно А.Левшину казахи вспоминали «золотой век» Таукехана, который правил с 1680 по 1718 гг. Отсутствие закона и порядка, оплакиваемого А.Левшиным, было результатом коллапса центральной власти в ситуации замороженнной русской имперской экспансией (Sneath, 2007:75-76,78-79).

Оспаривает Д.Сниз и один из главных аргументов, постулирующих отсутствие государственности у казахов: «В любом случае А.Левшин освещает регулярное налогообложение в предколониальный период согласно «большинству древних законов казахов. ...» (Sneath, 2007:79-80).

Проделанное автором переосмысление работ Левшина «совершенно ясно показывает, что «племена» фактически были административными подразделениями или атрибутами, созданными нисходящим процессом политической демаркации» (Sneath, 2007:80).

Характеризуя систему управления в степных государствах, Д.Сниз пишет: «Чингизиды, как монгольские Борджигины, так и казахские Ак Суйеки, не только монополизировали высокие посты, но они существовали в совершенно иной политической и правовой категории от своих подданных» (Sneath, 2007:128).

В целом, исходя из различных источников и работ номадоведов, структура верхушки Казахского ханства была аналогичной той, что существовала в Монголии (Гуревич, 1983:16,21).

Судебные фрункции выполняли султаны, бии, иногда несколько биев (в случае разбора межродовых споров), аксакалы. Бии составляли «касту» профессиональных хранителей юридических установлений и имели право на бийлик - десятую часть имущества ответчика. Наиболее влиятельные из биев входили в состав совета при ханах,который был постоянным органом власти. В 
то же время бии сочетали в себе три фуннции - родоначальника, судьи и представителя административной власти на местах. К числу чиновников можно в определенной степени отнести и туленгутов. Многие из них, находясь при ставке хана (султанов), выполняли различные поручения, собирали налоги, исполняли судебные решения, являлись гонцами и т.д.

Туленгутами называли лиц, находившихся на службе у султанского сословия. Появление этой прослойки, по мнению И.Ерофеевой, было связано с междоусобицами и многолетней борьбой с джунгарами, обусловившими большой спрос верховной власти на «служилых людей» (Ерофеева, 1999:36).

Делопроизводством занимались муллы, находящиеся при ставке хана и султанов. Известно, к примеру имя муллы Бабазяна, писаря хана Абылая (Гуревич, 1983:183).

Ханы, султаны и бии, - отмечал А. Левшин, - имеют у себя письмоводителей или мулл, которые читают им полученные бумаги и отвечают на оные (Левшин, 1996:35).

Можно полагать, что в ханских ставках у казахов были хронисты и литераторы. Примером тому является Кадир-Али-бий джалаир (1530-1605), находившийся при казахском султане Ураз (Ораз)-Мухаммеде, который стал правителем Касимовского ханства на Руси. Он погиб в период смутного времени. Кадир-Али-бий являлся автором работы, получившей условное название «Джами ат-Таврих» («Сборник летописей»), в которой нашла отражение история Казахского ханства (Березин,1854; Вельяминов-Зернов, 1864). Востоковед В.П.Юдин, на основании изучения различных документов, приходит к выводу о существовании канцелярий в Казахском ханстве (Юдин, 1983:18).

В последние годы, благодаря различным государственным программам в архивах Москвы, Пекина, Тегерана обнаружены письма казахских правителей государям вышеназванных держав, что подтверждает вывод В.П.Юдина.

Результаты. К началу изучаемого времени практически весь мир был поделен между несколькими державами. Сложилось несколько крупнейших империй, среди которых была и Российская. Одной из ее характеристик являлось то, что территория Российской империи, в отличие от других империй, представляла собой единое пространство (по большому счету, не являлась исключением и Аляска, отделенная от азиатских владений узким проливом), в которое к этому времени вошла и большая часть земель Казахского ханства. Население империи было чрезвычайно пестрым в этническом, конфессиональном, социальном, политическом и экономическом отношениях. Между народами, вошедшими в состав империи, существовали достаточно сложные, порой враждебные отношения. Для управления этими народами как прямого, так и косвенного, вырабатывались и применялись различные формы и методы. Не явилась исключением и образованная царским правительством в междуречье Волги и Урала Букеевская (Внутренняя) Орда. Как можно предположить, ее создание, фоормы и методы управления ею не являлись спонтанными, а прошли некую апробацию в различных местах в предшествующий период. В качестве таких прецедентов, вероятно, следует считать Касимовское и Калмыцкое ханства.

Касимовское ханство - удельное владение, бывшее в зависимости от Московского царя. Основано Касым-ханом, сыном Улуг-Мухаммеда. За верную службу Московскому князю он получил земли вдоль реки Оки. В 1567-1573 годах Касимовским ханством правил Саинбулат Бекбулатович, правнук последнего хана Золотой Орды Ахмата. В 1573 году он был крещен по 
православному обряду и получил имя Симеон. В 1575 году Симеон Бекбулатович стал царем и Великим князем всея Руси.

В 1600 году Касимовское ханство возглавил казахский царевич УразМухаммед. Он пытался выйти из-под зависимости русских правителей и создать самостоятельное государство. Но в 1610 году Ураз-Мухаммед был убит, и правителем был назначен внук Касим-хана Арслан (1610-1621), а затем сын Арслана Сеит-Бурхан (1627-1678) (Вельяминов-Зернов, 1864).

Номинально являясь независимым, Касимовское ханство все же зависело от русского царя. Возможно, что существование этого ханства было связано с тем, что для расширения территории царства на восток, требовалась легитимизация. Согласно идеологии чингисизма, править на землях входивших некогда в состав Золотой Орды имели право только члены «Золотого рода» (Юдин, 1983). Наличие же в составе Русского государства ханства, в котором правили чингизиды, позволяло легитимизировать осуществление экспансии.

Эта косвенная система управления, включившая много элементов изобретенной традиции, применялась и при управлении Калмыцким ханством.

В середине XVII в. русско-калмыцкие отношения вступают в новую стадию. Россия имела возможность предоставить калмыкам территорию для кочевок. В конце 50-х - начале 60-х годов XVII в. в основном определилась территория калмыцких кочевий в степях нижней Волги. После шерти 1657 г. калмыки стали нести военную службу Русскому государству, приняв тем самым главное условие, выдвигаемое русским правительством для окончательного оформления вхождения калмыцкого народа в состав Русского государства. Одновременно калмыкам было предоставлено право кочевать по берегам Волги. Две шерти 1661 г. окончательно урегулировали вопрос о совместных походах русских и калмыцких войск по планам и указам царского правительства. В ходе и в результате вхождения калмыков в состав России созданы были объективные экономические и политические условия для складывания особой калмыцкой государственности в форме ханства, вассального по отношению к царской власти.

Во главе калмыцкого государства начала 70-х годов XVIII в. стоял хан, хотя формальным верховным сюзереном всех территорий Калмыцкой степи был русский император. Хан управлял при помощи Зарго. Это учреждение имело двоякое значение: ханского совета, с одной стороны, и высшей судебной инстанции - с другой (Очерки, 1967: 125-128, 172, 181).

С 12 августа 1762 г., вступило в действие положение о Зарго, разработанное царскими властями. По новому положению суд Зарго составлялся из нойонов, представляющих все калмыцкие улусы, а не только один ханский. Состав Зарго отныне подлежал утверждению русского правительства. Все дела в Зарго теперь должны были решаться по большинству голосов, причем хан, в случае своего несогласия, уже не мог единолично своей властью отменить вынесенное постановление, а должен был просить у царского правительства разрешение на его отмену или изменение (Очерки, 1967:182).

После откочевки части калмыков из России Екатерина II 19 октября 1771 г. издала указ о ликвидации Калмыцкого ханства, упразднив при этом сами звания «хан» и «наместник ханства». Теперь все тайши становились совершенно независимыми друг от друга и должны были управлять своими улусами автономно, но под надзором русских властей. Ликвидировав Калмыцкое ханство, царское правительство осуществило общую перестройку аппарата управления калмыками. Их делами теперь стала ведать особа Экспедиция калмыцких дел, учрежденная при канцелярии астраханского губернатора. При правителях улусов были назначены приставы из числа русских чиновников (Очерки, 1967: 222). 
Имея такой опыт сначала косвенного, а затем и в большей степени прямого управления (а ведь описываемое, это только часть его), СанктПетербург сделал попытку применить его в отношении казахов Младшего жуза. Последний, в который входили все родовые объединения казахов, составивших впоследствии Букеевское ханство, принял Российское подданство в 30-х годах XVIII в.

Включение территории этого жуза в состав империи не могло не сопровождаться трансформацией системы управления. Как говорилось выше, в практике управления различных империй зависимыми территориями применялось две системы - прямая и непрямая (косвенная) (Томсинов, 1981).

«Младший жуз в конце XVIII - начале XIX вв. переживал один из наиболее трудных периодов своей истории. Внутриполитическая обстановка в нем была сложной и противоречивой. Усилилась политико-административная раздробленность региона, сказались последствия длительной (1783-1797 гг.) народной войны под руководством батыра Срыма, направленной против ханскосултанской власти. Престиж ханской власти упал до такой степени, что царское правительство серьезно думало об его упразднении. После убийства в 1797 г. повстанцами хана Есима был учрежден ханский совет (аналог калмыцкого Зарго), председателем которого и одновременно в фрамильном звании хана был определен престарелый султан Айчувак, но власть совета была малоэфффективной. Отделившиеся от хана родовые объединения провозглашали своих ханов. Прямое вмешательство колониальных органов во внутреннюю политическую жизнь жуза еще более осложнило обстановку (Зиманов, 1982:12).

Одним из задуманных ударов по традиционной системе управления была идея рассеивания ханской власти при номинальном сохранении последней. Екатерина II предписала оренбургскому генерал-губернатору следующее: «Но буде бы необходимость обстоятельств потребовала достоинства хана в орде восстановить, то и в таком случае полезнее держаться прежнего мнения об умножении их числа и чтобы каждый из таковых ханов не был силен в орде и зависел от вас, как и прочие подчиненные вам в губернии и по уездам » (Зиманов, 1982:15-16).

Образование Букеевского ханства. В начале XIX В. часть населения Младшего жуза сформировала между низовьями рек Волга и Урал новое этнополитическое образование, получившее по имени первого его хана название Букеевское ханство.

Сразу же отметим, что название «Букеевская Орда» впервые встречается в служебной документации чиновников около 1819 г., а «Внутренняя орда», применительно к этому же этнополитическому образованию с 1824 г. Оба этих термина использовались тогда параллельно с такими определениями как «подвластные Букей-султану киргиз-кайсаки» или «киргиз-кайсацкая Меньшая орда, кочующая в уральских и астраханских степях» (Ерофреева, 2002:8).

Причин образования этого ханства было много, но вероятно, что одной из главных являлось то, что «внутри Российской империи в пределах четко зафриксированной определенными административными границами территории было искусственно создано особое этнополитическое образование кочевниковказахов, которое рассматривалось царскими властями разных уровней в качестве удобного опытного полигона для последующего проведения различного рода инноваций на территории всей Казахской степи Оренбургского ведомства (Ерофеева, 2002:3).

Эта цель правительства косвенно подтверждается тем фрактом, что султана Букея к перекочевке за Урал, что явилось первым шагом для создания 
нового этнополитического образования, подталкивали царские чиновники, в частности полковник Попов, о чем свидетельствуют слова самого султана Букея : «...советы его (Попова - А.Г.) мне о кочевании между реками Волгой и Уралом нашел я благополезнейшими...» (Письмо, 2002:28).

11 марта 1801 г. Павел I издал указ, санкционировавший переход хана Букея в междуречье Волги и Урала.

Территориальные пределы расселения этих мигрантов в междуречье Урала и Волги были определены 19 мая 1806 г. специальным положением царского правительства «О назначении земель калмыкам и другим кочующим народам в губернии Астраханской", утвержденным царем. В нем говорилось, что «киргиз-кайсакам под предводительством султана Букея дозволено кочевать, начиная от р. Узеня до горы Богдо... и от сей горы через Чапчачи на ватагу Дудатскую или Телепневу до моря». Небольшой части казахов разрешалось иметь зимовки (кстау) «при море, между ватагою Дудатской, Телепневой и Коневской, а остальным - при камышах на свободных землях». По исчислению дореволюционного исследователя А. Евреинова, общая земельная площадь Внутренней орды составляла тогда 6,5 млн. десятин; из них земель, пригодных для пастбищ, было 5,2 млн. десятин, бесплодной степи - 192 тыс. десятин, песку - 420 тыс. десятин» (Ерофеева, 2002:6).

Указом императора от 17 июля 1808 г. было установлено двойное подчинение нового ханства. Оно подчинялось как Астраханскому военному губернатору, так и Оренбургской пограничной комиссии, созданной для управления казахами Младшего жуза.

Ханская власть. Султан Букей после перехода на другую сторону Урала стал именовать себя ханом. В то же время, до официального провозглашения ханства в 1812 г., российские власти в официальных документах именовали его султаном.

По мнению С.З. Зиманова, «Букеевское ханство по форме организации высшей власти являлось монархией. Верховная власть в нем принадлежала хану и передавалась по наследству» (Зиманов, 1982:91).

Как считал С.3. Зиманов, это ханство в плане структуры и механизмов управления было типичным образцом организации традиционной ханской власти в Казахстане, но со второй четверти XIX в., оно трансформируется в монархию с ярко выраженной централизацией власти. Родоправители и старшины больших родовых отделений (аналог административных единиц в понимании Д. Сниза - А.Г.) назначаются ханом и становятся его наместниками. Свободные духовные лица заменяются институтом указных лиц, также назначаемых ханом. Уничтожается прежняя самостоятельность родов, исполнительная и судебная власть из сферы общины переходит в руки хана. Все местные правители подчиняются правителям более крупных родовых подразделений. Устанавливается единая налоговая и финансовая система. Осуществляется план перераспределения и использования земельных угодий, включая и сезонные пастбища (Зиманов, 1982:91).

Между тем, нововведения санкционируются традиционными институтами и идеологией чингисизма. В частности, султан Букей не удовлетворяется прежним титулом, который в традиционной системе Казахского ханства означал его положение в качестве наместника хана. Поэтому он провозглашается ханом Внутренней орды. Его интронизация проходит в соответствии с существовавшим ритуалом «хан-кутурмак» (о семантике ритуала см. - Галиев, 2015) 
Но окончательное утверждается он в этом звании царским правительством. 7 июля 1812 г. в присутствии высших чинов Оренбургской администрации во главе с губернатором Волконским, неподалеку от г. Уральска султан Букей был официально возведен в ханы Внутренней орды. Дублирование ритуала, присутствие царских чиновников, придававших тем самым этому действу законный характер, заставляет нас считать этот ритуал изобретенной традицией.

После смерти Букея решался вопрос о новом хане. 22 июня 1824 г. решение об избрании ханом Джангира было подписано императором. 24 июня в г.Уральске в присутствии высших чинов из Оренбурга произошло официальное провозглашение его ханом.

Хан Джангир смотрел на Букеевскую Орду как на свое поместье, собственное владение, где он пожелал иметь почти неограниченную власть над простыми казахами. И, действительно, в пределах Орды он достиг этого. В Орде высшим авторитетом был только хан, а родоправители - султаны, бии и старшины - находились в зависимости от него.

В целях накопления богатства хан Джангир перенес в Орду систему поместного хозяйства русского дворянства и методами этой системы он стал эксплуатировать казахов. Хан захватил себе самые лучшие земли, произвольно раздавал общественные земли султанам и старшинам, простым казахам жаловал тарханство, возводя их в дворянское сословие. Помимо всего этого хан продавал и перепродавал частным лицам общественные земли (Аспандияров, 2007).

Джангир-хан одновременно с этими нововведениями, реформировал налоговую систему и приступил к созданию центрального аппарата управления. Последний включал в себя подразделения различной функциональной направленности. Наиболее влиятельной силой была группа ханских депутатов, в обязанности которых вменялось: следить за положением дел на границе и пресекать самовольный переход казахов через нее; участвовать в разборе спорных вопросов между казахами и русскими; сопровождать русских чиновников и оказывать им содействие и др.

В 1827 г. Джангир объявил об учреждении Совета биев, в состав которого входили по одному бию от каждого родового подразделения. Члены совета в официальных документах именовались «бий ханского совета» или «бий и советник хана», иначе говоря, этот совет являлся все тем же Ханским советом, существовавшим и в Младшем жузе, и в Калмыцком ханстве. Совет был постоянно действующим органом и проводником политики императора и хана.

Впервые в истории Казахстана в Букеевском ханстве Джангир учредил должность ахуна, исполнявшего также обязанности ханского духовного судьи.

17 апреля 1828 г. Оренбургская пограничная комиссия предложила Джангиру именоваться ханом киргизов Внутренней Орды, хотя он претендовал на звание хана всего Младшего жуза".

В Орде сложился институт есаулов, которые привлекались для выполнения специальных важных поручений хана. Этот институт, как по составу, так и по выполняемым задачам отличался от ранее существовавших шабарманов.

Для регулярной связи с родами была образована группа ханских вестовых. При хане находилась канцелярия, делившаяся на основную (русскую) и

\footnotetext{
${ }^{1}$ Центральный Государственный архив Республики Казахстан (далее ЦГА РК) ЦГА РК, Ф.И-78. Оп.1.Д.20, л.133 и об.
} 
татарскую. Впервые в степи была учреждена должность ахуна - главного духовного лица в ханстве.

Аппарат управления поддерживался военной командой состоящей из астраханских и уральских казаков и астраханских калмыков.

Ликвидация Букеевского ханства. Курс, направленный на ликвидацию традиционных институтов управления, существовавших на территории казахской степи, целенаправленно проводимый царским правительством, завершился упразднением ханской власти в Среднем жузе в 1822 г., и в Младшем жузе чуть позже, в 1824 г.

Букеевское ханство, будучи попыткой приспособления традиционных институтов к новым условиям существования, или «изобретенной традицией» продержалось еще два десятилетия. После смерти хана Джангира в 1845 г. управление было передано Временному совету, возглавлявшемуся в первое время одним из родственников хана Джангира.

Затем его возглавил русский чиновник, назначаемый Петербургом. Но вопрос о назначении нового хана не снимался царским правительством вплоть до середины 1850-х годов, когда ханская власть была окончательно ликвидирована. Косвенное правление в этой части Российской империи стало прямым, хотя правительство пыталось и в дальнейшем приспособить некоторые элементы традиционных институтов управления к новым реалиям.

Заключение. Историю возникновения, развития и упразднения Букеевского ханства, - как справедливо пишет С.3. Зиманов, - нельзя рассматривать в отрыве от присоединения Казахстана к России (Зиманов, 1982:4). Уникальность ханства заключается в том, что оно было создано по инициативе царских чиновников в непосредственной близости от центра империи, что В определенной степени напоминает сценарий создания Касимовского ханства. Создание ханства преследовало определенную цель создать и «обкатать» модель управления, приемлемую для дальнейшего внедрения в присоединяемых казахских землях. Российская империя, сыграла ключевую роль в становлении рассматриваемого административнополитического образования и определила его природу как изобретенной традиции. В случае с Букеевским ханством, здесь само это ханство стало изобретенной традицией.

В управлении ханством можно выделить следующие этапы. На первом использование традиционных институтов. Затем их ослабление, подрыв авторитета, внедрение изобретенных институтов и традиций. На втором этапе, переход от косвенного управления к комбинированному и затем, к прямому. Этот этап завершается ликвидацией ханской власти не только на территории Букеевского ханства, но и во всей казахской степи.

\section{Әдебиеттертізімі / Список литературы}

1. Андерсон , 2001 - Андерсон Б. Воображаемые сообщества. Размышления об истоках и распространении национализма / Пер. с англ. В. Николаева; Вступ. ст. С. Баньковской. - М.: «КАНОН-пресс-Ц», «Кучково поле», 2001. 288 с.

2. Аспандияров, 2007 - Аспандияров Б. Образование Букеевской Орды и ее ликвидация. Алматы: Казак энциклопедиясы, 2007.

3. Березин, 1854 - Березин И.Н.Библиотека восточных историков. Т.2. Ч.1. - Казань, 1854.

4. Вельяминов-Зернов, 1864 - Вельяминов-Зернов В.В. Исследования о касимовских царях и царевичах. - Спб., 1864.

5. Галиев, 2015 - Галиев А.А. Казахское ханство: структура, экстра-образ и знаковый аспект. Алматы, 2015.

6. Гуревич, 1983 - Гуревич В.П. Международные отношения в Центральной Азии в XVII - пер. пол. XIX в. М.: Наука. 1983. 
7. Ерофеева,1999 - Ерофеева И.В. Хан Абулхаир: полководец, правитель, политик. - Алматы: Санат,1999.

8. Ерофеева, 2002 - Ерофеева И.В. Внутренняя, или Букеевская орда в первой половине XIX в.: История и историография // История Букеевского ханства. 1801 - 1852 гг.: Сб. документов и материалов / Сост. Б.Т. Жанаев, В.А. Иночкин, С.Х. Сагнаева. - Алматы: Дайк-Пресс, 2002.

9. Крупенкин, 2018 - Крупенкин Е.Н. Туркестан в составе Российской империи (1865-1917 гг.): от военно-административного управления к гражданско-административному 07.00 .02 Отечественная история дис. на соиск. уч.ст.к.и.н.. - Томск, 2018.

10. Зиманов, 1982. - Зиманов С.3. Россия и Букеевское ханство. - Алма-Ата: Наука, 1982. - 171 с.

11. Кундакбаева, 2014 - Кундакбаева Ж. Изобретение традиций: репрезентация Российской империи среди кочевников Северного Прикаспия в XVIII веке. ActaSlavicalaponica, Tomus 35, pp. 27-53.

12. Левшин, 1996 - Левшин А. Описание киргиз-казачьих или киргиз-кайсацких орд и степей. Алматы: Санат, 1996.

13. Очерки, 1967 - Очерки истории Калмыцкой АССР. Дооктябрьский период. Москва: Наука, 1967. Очерки истории Калмыцкой АССР. Дооктябрьский период. - Москва: Наука, 1967.

14. Письмо, 2002 - Письмо председателя Ханского совета Младшего жуза Букея Нуралиханова командующему Кавказской линией пехоты генерал-лейтенанту К.Ф.Кноррингу с просьбой о принятии в российское подданство и предоставлении постоянных кочевий в междуречье Урала и Волги от 11 февраля 1801 г. // Бирюков И.А. Служба астраханских казаков на кордонных постах против киргиз-кайсаков (1794-1861 гг. ) и при ставке хана Внутренней киргизской орды (18011899 гг.). Астрахань, 1901. - С.14-16. - Цит. по: История Букеевского ханства. 1801 - 1852 гг.: Сб. документов и материалов / Сост. Б.Т. Жанаев, В.А. Иночкин, С.Х. Сагнаева. - Алматы: ДайкПресс, 2002.

15. Томсинов, 1981 - Томсинов В.А. Источники британского «колониального права» в Тропической Африке (начало XIX - середина XXв.) Специальность № 12.00 .01 - теория и история государства и права; история политических и правовых учений. дис. на соиск. уч. ст. к.ю.н. Москва, 1981.

16. Трепавлов, 2001 - Трепавлов В. Был ли Казахстан российской и советской колонией? // Российские вести, 31 мая 2001 года

17. Хобсбаум, 1983 - Хобсбаум Эрик. Изобретение традиций / Перевод осуществлен no изданию: ThelnventionofTradition. Edited by Eric Hobsbawm and Terence Ranger. Cambridge University Press, 1983. - P. 1-14.

18. Юдин, 2001 - Юдин В.П. Центральная Азия в XIV-XVIII веках глазами востоковеда. - АлмаАта: Наука, 2001.

19. Юдин, 1983 - Юдин В.П. Орды: Белая, Синяя, Серая, Золотая // Казахстан, Средняя и Центральная Азия в XVI-XVIII вв. - Алма-Ата: Наука, 1983. - С.106-164.

\section{References}

Anderson, 2001 - Anderson B. Voobrazhaemye soobshchestva. Razmyshleniya ob istokah i rasprostranenii na cionalizma / Per. s angl. V. Nikolaeva; Vstup. st. S. Ban'kovskoj. - M.: «KANON-press-C», «Kuchkovo pole», 2001. - 288s. [In Rus.].

Aspandiyarov, 2007 - Aspandiyarov B. Obrazovanie Bukeevskoj Ordy i ee likvidaciya. - Almaty: Kazak enciklopediyasy, 2007. [In Rus.]

Berezin, 1854 - Berezinl.N. Bibliotekavostochnyhistorikov.T.2. CH.1. - Kazan', 1854. [In Rus.]

Vel'yaminov-Zernov, 1864 - Vel'yaminov-Zernov V.V. Issledovaniya o kasimovskihcaryahicarevichah. Spb., 1864. [In Rus.]

Galiev, 2015 - Galiev A.A. Kazahskoe hanstvo: struktura, ekstra-obraz i znakovyj aspekt. - Almaty, 2015. [In Rus.]

Gurevich, 1983 - Gurevich V.P. Mezhdunarodnye otnosheniya v Central'noj Azii v XVII - pervoj polovine XIX v. - M.: Nauka. 1983. [In Rus.]

Erofeeva,1999 - Erofeeva I.V. Han Abulhair: polkovodec, pravitel', politik. - Almaty: Sanat,1999. [In Rus.]

Erofeeva, 2002 - Erofeeva I.V. Vnutrennyaya, ili Bukeevskaya orda v pervojpolovine XIX v.: Istoriya i istoriografiya // Istoriya Bukeevskogo hanstva. 1801 - 1852 gg.: Sb. Dokumentov i materialov / Sost. B.T.ZHanaev, V.A.Inochkin, S.H.Sagnaeva. - Almaty: Dajk-Press, 2002. [In Rus.]

Krupenkin, 2018 - Krupenkin E.N. Turkestan v sostave Rossijskoj imperii (1865-1917 gg.): ot voennoadministrativnogo upravleniya $\mathrm{k}$ grazhdansko-administrativnomu 07.00 .02 - Otechestvennaya istoriya Dissertaciya na soiskanie uchenoj stepeni kandidata istoricheskih nauk. - Tomsk, 2018. [In Rus.]

Zimanov, 1982.- Zimanov S.Z. Rossiyai Bukeevskoe hanstvo. - Alma-Ata: Nauka, 1982. $171 \mathrm{~s}$. [In Rus.] 
Kundakbaeva, 2014 - Kundakbaeva ZH. Izobretenie tradicij: reprezentaciya Rossijskoj imperii sredi kochevnikov Severnogo Prikaspiya v XVIII veke. Acta Slavica laponica, Tomus 35, pp. 2753. [In Rus.]

Levshin, 1996 - Levshin A. Opisanie kirgiz-kazach'ih ili kirgiz-kajsackih ord i stepej. - Almaty: Sanat, 1996.[In Rus.]

Ocherki, 1967 - Ocherki istorii Kalmyckoj ASSR.Dooktyabr'skij period.Moskva: Nauka, 1967. Ocherki istorii Kalmyckoj ASSR.Dooktyabr'skij period. - Moskva: Nauka, 1967. [In Rus.]

Pis'mo, 2002 - Pis'mo predsedatelya Hanskogo soveta Mladshego zhuza Bukeya Nuralihanova komanduyushchemu Kavkazskoj liniej pekhoty general-lejtenantu K.F.Knorringu s pros'boj 0 prinyatii v rossijskoe poddanstvo i predostavlenii postoyannyh kochevij v mezhdurech'e Urala i Volgi ot 11 fevralya $1801 \mathrm{~g}$. // Biryukov I.A. Sluzhba astrahanskih kazakov na kordonnyh postah protiv kirgiz-kajsakov (1794-1861 gg. ) i pri stavke hana Vnutrennej kirgizskoj ordy (1801-1899 gg.). Astrahan', 1901. - S.14-16. - Cit. po: Istoriya Bukeevskogo hanstva. 1801 - 1852 gg.: Sb. dokumentov i materialov / Sost. B.T. ZHanaev, V.A. Inochkin, S.H. Sagnaeva. - Almaty: DajkPress, 2002. [In Rus.]

Tomsinov, 1981 - Tomsinov V.A. Istochniki britanskogo «kolonial'nogo prava» v Tropicheskoj Afrike (nachalo XIX - seredina XX v.) Special'nost' № 12.00.01 — teoriya i istoriya gosudarstva i prava; istoriya politicheskih i pravovyh uchenij. Disser. na soisk. Uc. St. K.u.n. Moskva,1981. [In Rus.]

Trepavlov, 2001 - Trepavlov V. Byl li Kazahstan rossijskoj i sovetskoj koloniej? // Rossijskie vesti, 31 maya 2001 goda

Hobsbaum, 1983 - Hobsbaum Erik. Izobretenie tradicij / Perevod osushchestvlen no izdaniyu: ThelnventionofTradition. Edited by Eric Hobsbawm and Terence Ranger. Cambridge University Press, 1983. - P. 1-14. [In Rus.]

YUdin, 2001 - Yudin V.P. Central'naya Aziya v XIV-XVIII vekah glazami vostokoveda. - Alma-Ata: Nauka, 2001. [In Rus.]

YUdin, 1983 -Yudin V.P. Ordy: Belaya, Sinyaya, Seraya, Zolotaya // Kazahstan, Srednyaya i Central'naya Aziya v XVI-XVIII vv. - Alma-Ata: Nauka, 1983.- S.106-164. 